\title{
Courses and Employability Skills: The Voice of Students
}

\author{
Li GAO ${ }^{1, a,{ }^{*}}$, Xia WANG ${ }^{2, b}$, Ya-Ping CUI ${ }^{1, c}$ \\ ${ }^{1}$ College of Foreign Languages, Northwest University, Xi'an, Shaanxi, China \\ ${ }^{2}$ Institute of Education, Nanjing University, Nanjing, Jiangsu, China \\ aligao@nwu.edu.cn, ${ }^{b} x i a 0 x i a 02003 @ v i p .163 . c o m,{ }^{c}$ cuiyp001@163.com \\ ${ }^{*}$ Corresponding author
}

Keywords: Students' perception, Core discipline courses, Employability skills.

\begin{abstract}
Graduate employability has become a growing concern for many countries. Curricula are playing a critical role in fostering graduate employability. This paper explores the student perceptions of their programs and its relevance wtih their employability skills. 1809 senior students of ten higher education institutions (HEIs) of Jiangsu Province of China were surveyed and found that 1) students regardless of their fields of study are generally not very satisfied their core discipline courses,; 2) students are more satisfied with the contents of their core discipline courses, and the learning resources but dissatisfied with the current sequence of their courses; 3) students do not think highly of the relevance of their courses and the employability skills needed by future employment; 4) the number of students who would like to take discipline-related jobs after graduation is slightly over $1 / 3$.
\end{abstract}

\section{Introduction}

Young people employment has increasingly become an issue of great concern nationally and internationally. Recent reports like Be Skilled, Be Employed, Be the Change Generation [1] and Europe2020 [2] clearly demonstrate that the cultivation of employability skills to obtain employment has become the their top priority. Likewise, in China the government also has attached considerable importance to the issue and particular attention has been paid to graduates employment. The advancement of the massification of higher education has made the issue become more prominent. Before 1999 the opportunities of getting enrolled in HEIs are rare and it is still a privilege for a few elites, and the problem of obtaining a job did not seem to be a problem at all. It is in 1998 that the term "employment" first appeared in the official documents, namely in the 59th article of the Higher Education Act [3] , which has made it an obligation for HEIs to provide relevant careers service and guidance to help students secure employment.

After that as higher education enrollment opportunities have been expanded more students who may be under-qualified and not be able to attend universities in the past, now swarm into campuses. This worsens the problem of finding employment. A question has been posed to universities: How to prepare those less qualified cohort to meet the demands of the labour market? What are the employability skills sought after by employers and should be acquired by graduates? How relevant are the HEIs courses are with fostering employability skills?

The first two questions have been answered by the previous researches and will be detailed in the part of literature review, and the third question will be the focus of this study and ten HEIs of Jiangsu Province of China are taken as sample to explore the issue and hopefully may shed some light for other HEIs and similar researches.

\section{Literature review}

The discussion of higher education and employability skills is not new. In 1963 British government already commissioned a committed to investigate the problem, and the publication of Robbins Report suggested that "instruction in skills suitable to play a part in the general division of labour" [4]. The skills mentioned here are those conferred by universities [4]. 
Later in 1990s similar idea was put forward by the Dearing Report. This is another significant report commissioned by British government. It asserted that "education and training enable people in an advanced society to compete with the best in the world" [5]. Universities are put at a position to prepare students ready for the world of work. The similar voice was also found in the United States. The publication of SCANS (Secretary's Commission on Acquiring Necessary Skills) report of American government has underlined the importance of the acquisition of necessary skills for future success of work [6]. The five categories of competences emphasized are to productively use resources, interpersonal skills, information, systems and technology.

The discussion of employability skills have become the growing interest of governments and researchers since then. As to the connotations of employability, a few widely-recognized definitions have already formed. Of them Hillage and Pollard [7] put employability as "the capability to move self-sufficiently within the labour market to realize potential through sustainable employment". Knight and Yorke [8] define it as "a set of achievements, understandings and personal attributes that make individuals more likely to gain employment and be successful in their chosen occupations". Besides, the Conference Board of Canada (2014) depicts that employability skills are the skills needed to enter, stay in and progress in the world of work [9].

It can be seen that researchers generally agree with the role of employability skills play in obtaining employment, and employability skills are described as capability, a complex set. But then what exactly do they comprise if they are to be taught or examined? Since the employability skills are those skills sought by employers, their ideas may be industry-oriented and also largely affected by the economy and culture of the country they are in. It would be not possible to supply a fit-for-all set of components of employability skills. The inventory adopted in this paper is the findings of a research project commissioned by National Social Sciences Foundation of China, which surveyed employers of major cities in China. The employability skills listed are discipline knowledge and skill, employment awareness, self management, interpersonal skill, team working, communication skill, problem solving skill, leadership, innovation.

Employability skills are believed to play a critical role in helping graduates get decent jobs that match their education and training [10]. The model developed by McQuaid and Lindsay(2005) indicates there are three components that influence employability skills, namely, individual factors, personal circumstances and external factors [11]. Among them the first factor is where the universities may start with. A better designed program can foster their graduate employability skills better. Chinese researchers have realized the importance of the cultivation of graduate employability skills and taken curricula and program as the place to start. Some suggest that the current careers service and guidance should be improved. Others like [12] and [13] stated that the key lies in the adaptation of the whole curriculum structure.

This paper concurs with the theory of [12]) and [13] that courses structure of their programs is co-related with graduate employability and then the employment rates. It will therefore examine the undergraduate programs of Jiangsu Province of China, and analyze the distribution of the different types of courses and the employability skills perceived by students. This paper especially focuses on the core discipline courses and employability skills of students. The economy and the development of higher education in Jiangsu Province has been at a leading position in China, and a survey of its HEIs undergraduate programs would be insightful for other HEIs.

\section{Research design}

\section{Research questions}

The main research question addressed in the study is how relevant HEIs courses are with fostering employability skills, and the courses examined here are the core discipline courses of their programs. To get a clear picture the research question is further divided into the following questions.

1 Are students satisfied with their current programs in terms of teaching quality? 
2 How do they think of the relevance of their programs with employability skills?

3 Are they aware of the skills required by their future employment?

4 Are they going to take discipline-related job after graduation?

Besides finding answers for the above questions the differences of students' perceptions between different disciplines backgrounds will be explored to investigate the variance that may exists there.

\section{Subjects}

Subjects of the study are random-selected senior students of ten HEIs of Jiangsu Province (China). The ten HEIs are located in six cities and cover the northern, middle and southern part of Jiangsu Province. Of the ten HEIs four are in the northern part, another six are equally divided in the middle and the southern part. These universities are mainly provincial universities and their finding largely comes from the province. Their main function is in teaching instead of research. The disciplines these students are in include the areas of humanities and social sciences, sciences, and engineering. First cycle education in China normally lasts four years and senior students are at a better position to evaluate the programs they have undertaken.

\section{Instrument}

The questionnaire used in the study is borrowed from the one designed by the research team that the researcher is in and was implemented in completing the survey of students of other parts of China. Its reliability and validity have been tested and could collect the data that this study needs. The questionnaire has two parts. The first part is about the demographic data of the subjects, and the second asks them to evaluate their core discipline courses. The items are worded in Chinese, the native language of the students, to ensure an accurate understanding of them. Subjects need to rate each item based on their own perceptions. The first item asks students to tick the box corresponding to their discipline area. The second one is the evaluation of the teaching quality in terms of contents taught, teacher qualifications, courses sequencing, learning recourses, and classroom teaching hours. Lickert scale of 1 to 5 is used here. If the statement completely matches what the student thinks, s/he ticks the box called completely match and a value of 5 is attributed to it. If the statement doesn't match what the student thinks at all, s/he then ticks the box called not match at all and a value of 1 is attached to it. The third item is to evaluate the relevance of courses with employability skills at a scale of 5 to 1.5 stands for very high relevance while 1 is very low relevance. Next item is about their awareness of the skills required for their future employment, and a scale of 3 to 1 is used. The 3 refers to "know", and 1 is "don't know". The last item is about their intention of taking discipline-related job after graduation.

\section{Data collection}

The subjects are senior students of six universities of Jiangsu Province and are randomly selected. To collect the data from each university a particular student affairs teacher of each university was contacted and agreed to be in charge of the implementation of the questionnaire. Relevant training was provided to clarify the aims of the study and procedure of data collecting. The questionnaire was distributed in April 2012 and was mailed back after completion. All the data was sent back before the end of May. A total number of 1809 survey forms were distributed and 1672 responses are valid. The valid return rate is $92.43 \%$.

\section{Survey results}

\section{Profile of the respondents}

The analysis of the first part of the instrument indicates the distribution of the gender, and their discipline areas, which can be found in Fig. 1 and 2 below.

Evaluation of core discipline courses. Table 1 indicates the respondents' ratings of curriculum in terms of contents, teaching, sequence of courses, learning resources and credit hours. The ratings of curriculum of correspondents of different disciplines are compared in Fig.3. 


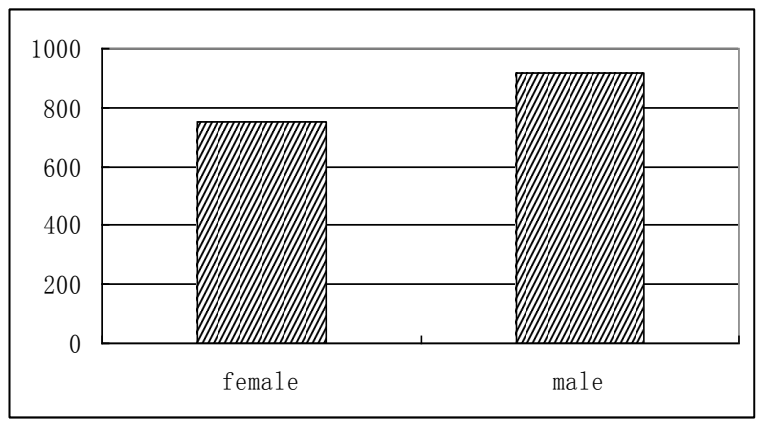

Fig.1 Profile of respondents by gender

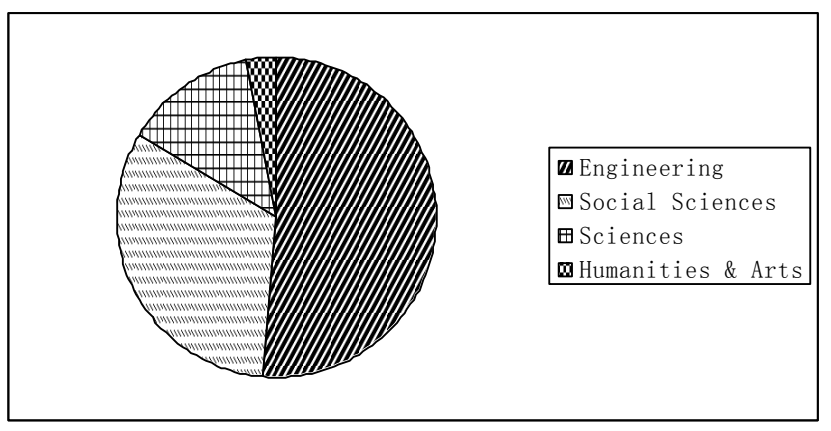

Fig.2 Profile of respondents by discipline

Table 1 Respondents' ratings of curriculum

\begin{tabular}{lllllll}
\hline & \multicolumn{2}{c}{$\begin{array}{c}\text { Number of } \\
\text { respondents }\end{array}$} & $\begin{array}{c}\text { Minimum } \\
\text { value }\end{array}$ & $\begin{array}{c}\text { Maximum } \\
\text { value }\end{array}$ & Mean & $\begin{array}{c}\text { Standard } \\
\text { deviation }\end{array}$ \\
\hline contents & 1672 & 1 & 5 & 3.70 & .454 \\
teaching & 1672 & 1 & 5 & 3.65 & .491 \\
sequence of courses & 1672 & 1 & 5 & 3.52 & .552 \\
learning resources & 1672 & 1 & 5 & 3.70 & .475 \\
credit hours. & 1672 & 1 & 5 & 3.68 & .536 \\
\hline
\end{tabular}

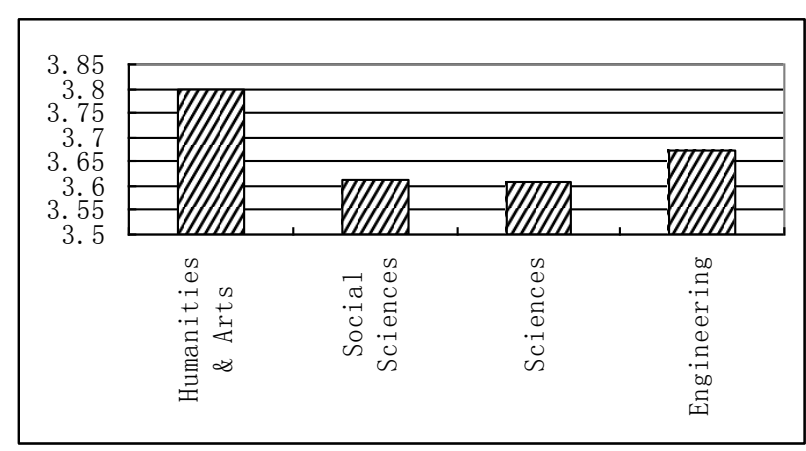

Fig. 3 Respondents' ratings by discipline

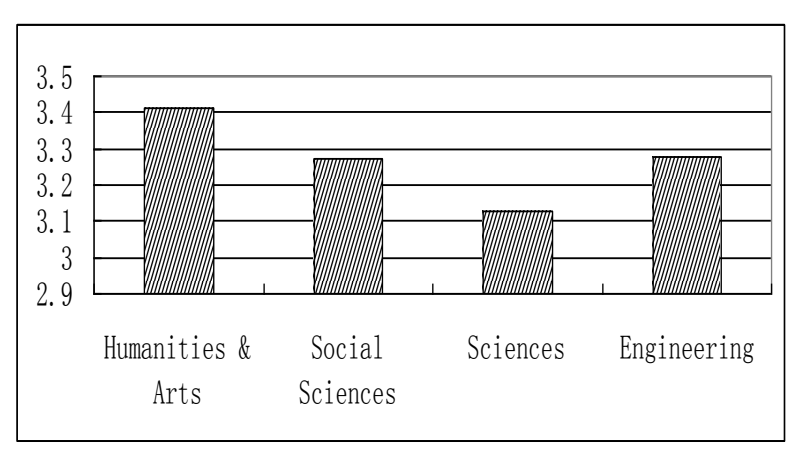

Fig.4: Comparison of relevance of core discipline courses and employability skills by discipline

Relevance of core discipline courses and employability skills. The relevance of core discipline courses and the development of employability skills of different disciplines are compared in Fig. 4.

Intention of taking discipline-related employment. Table 2 shows the intentions of respondents of different disciplines after graduation.

Table 2: Intentions of respondents of different disciplines after graduation

\begin{tabular}{llllr}
\hline \hline & Not sure & No & Yes & Total \\
\hline Humanities \& Arts & $29.3 \%$ & $14.6 \%$ & $56.1 \%$ & $100.0 \%$ \\
Social Sciences & $50.5 \%$ & $18.0 \%$ & $31.5 \%$ & $100.0 \%$ \\
Sciences & $42.7 \%$ & $29.8 \%$ & $27.5 \%$ & $100.0 \%$ \\
Engineering & $37.1 \%$ & $21.2 \%$ & $41.6 \%$ & $100.0 \%$ \\
$\quad$ Total & $41.9 \%$ & $21.1 \%$ & $36.9 \%$ & $100.0 \%$ \\
\hline
\end{tabular}




\section{Discussion}

\section{Respondents' perceptions of curricula}

It is very interesting to find that the number of male respondents is higher than that of female ones, and the fact that $51.4 \%$ of respondents are in the field of engineering may help to explain this phenomenon since there tend to be more male students who would like to take the engineering courses. Another large group of respondents comes from social sciences. Respondents of this two disciplinary areas constitute $83.7 \%$ of the sample. In a sense it can be said that the findings largely reflect the perceptions of students of this two disciplinary areas.

It can be found that generally respondents are not very satisfied with the curricula they have already taken, and the mean is 3.6488 while the maximum value is 5 and the minimum is 1 . Obviously the current curricula do not match what respondents expected. An analysis of learners' needs analysis is suggested to be conducted so as to fit learners better.

A further analysis of respondents' perception of curricula in terms of contents, teaching, sequence of courses, learning resources and credit hours demonstrates that both contents and learning resources have the highest ratings, and the one that respondents are dissatisfied most is the sequence of courses.

Of the four disciplines respondents of humanities and arts seem to be more satisfied with their core discipline courses. Those from social sciences and sciences may seem to be not very satisfied with their courses. However, the statistical test of differences is not significant and that means respondents regardless of their fields of study do not think highly of their core discipline courses. This clearly implies that the courses of the HEIs of Jiangsu Province need to be improved and it is a universal problem for all the disciplines.

\section{Relevance of core discipline courses and employability skills}

What is surprising about the relevance of core discipline courses and respondents employability skills is that the rating is only 3.26 while the maximum value is 5 . This reveals that the core discipline courses of all the disciplines are not perceived to be effective in developing students' employability skills. Once again it shows students' disapproval of their current courses and do not think they are relevant in fostering their skills.

Respondents of sciences are those who rated the relevance of courses and skills lowest while those of humanities and arts rated it higher. The different ratings existing between them may have something to do with the nature of the disciplines. The field of sciences tends to be pure and abstract and may not be easy to understand the possible connection between it and the skills for employment. One thing that needs to mention is that respondents of engineering students' rating is quite low, which is only 3.28, and this should make those directors of engineering programs ponder and take some measures to adapt courses and build up more linkage between program and future employment.

However, one point that needs to mention is that the rating result of this part is based on what respondents understand about their core discipline courses and their expectations for their future employability. If they know a little, or even do not know anything about the employments awaiting them, it would be pointless to ask them to rate the relevance.

\section{Awareness of employability skills required by future employment}

Are respondents fully aware of the employability skills that their future employment needs? If they have sufficient knowledge of that, they would be able to make sound judgment about the connection between courses and skills. The truth is that about $1 / 4$ of them know the skills needed for employment while over $2 / 3$ only know a little. This hard fact seems to imply that students are not able to evaluate the relevance between courses and skills since they do not know much about what is needed. On the other hand another inference can be made from this is that there is quite a large scope for schools to work on and make those information related to employability skills and employment more accessible to students.

\section{Intentions of employment after graduation}

As to respondents' plan after graduation only a little over $1 / 3$ of them are sure that they will take jobs relevant with the program they are in. Almost half of respondents are not clear about their future 
employment. It is hard to imagine that one could put his efforts and energy in something that he is not very interested in. This also reflects that there is still much work to do in careers education so as to help students find the right type of jobs. The worrying figure is that over 1/5 of respondents indicate clearly they will not take the jobs related with what they have learned. Reasons behind this should be explored. Some students come to universities just for academic credentials instead of pursuing what they really are interested in, and the programs they are in may not be their free choice but the will of their parents. They may listen to their parents and get enrolled, but still find himself/herself not interested in that at all.

\section{Conclusions}

The conclusions can be drawn from the above findings and discussions are listed below:

- Respondents of the study generally are not satisfied with their core discipline courses and there is no significant difference between students of different disciplines.

- As to the specific component of curricula respondents are more satisfied with the contents they have learned and the learning resources they have, but disapprove the current sequence of their courses.

- Respondents' ratings of the relevance of their courses and employability skills are not satisfactory and one reason lies in the fact they do not have sufficient knowledge of employment or employability skills.

- Only $36.2 \%$ respondents are positive that they would like to take discipline-related jobs after graduation. This is worth considering when it comes to evaluating or reforming courses

\section{Acknowledgement}

This research was financially supported by National Social Sciences Foundation (Grant No. 10BSH038), Social Sciences Research Program of Ministry of Education (Grant No. 10YJA740136), Postgraduates Research Program of Universities of Jiangsu Province(Grant No. CXZZ12_0016), Social Sciences Research Program of Education Department of Shaanxi Province (Grant No. 2013JK0407) and research project of College of Foreign Languages of Northwest University.

\section{References}

[1] Information on http://unesdoc.unesco.org/images/0021/002184/218409e.pdf.

[2] Information on http://ec.europa.eu/eu2020/pdf/COMPLET\%20EN\%20 BARROSO\%20\% $20 \% \% 20-\% 20$ Europe \% 202020\%20-\%20EN\%20version.pdf.

[3]Information on http://www.moe.gov.cn/publicfiles/business/htmlfiles/moe/moe_619/200407/ 1311.html.

[4] Information on http://www.educationengland. org.uk/documents/robbins/robbins1963.html.

[5] Information on http://www.leeds.ac.uk/educol/ncihe/.

[6] Information on http://www.uni.edu/darrow/frames/scans.html, 2013-09-10.

[7] J. Hillage, E. Pollard, Employability: Developing a Framework for Policy Analysis, Department for Education and Employment, London, 1998.

[8] P. T. Knight, M. Yorke, Assessment, Learning and Employability, Society for Research into Higher Education and Open University Press, Maidenhead, 2003.

[9] Information on http://www.conferenceboard.ca/topics/education/learning-tools/employabilityskills.aspx.

[10] Information on http://unesdoc.unesco.org/images/0021/002157/215706e.pdf.

[11] R. W. McQuaid, C. Lindsay, The Concept of Employability, Urban Studies, 2(2005) 197-219. 
[12] J. Xu, H. Fu and S. Long, Undergraduate Curriculum Design towards Labour Market Needs: an Economic Perspective, Tsinghua Journal of Education, 5(2008)22-28.

[13] X. Wang, X. Qian, The Adjustment of Higher Education Curriculum Structure and Employment of University Students: the Analysis based on Job Search Theory, Tsinghua Journal of Education, 3(2012) 21-27. 